\title{
"They will liberate themselves": Education, Citizenship, and Civil Rights in the Appalachian Coalfields
}

\author{
Kristan L. McCullum \\ School of Education and Human Development, University of Virginia, Charlottesville, VA \\ Corresponding author. Email: km3jw@virginia.edu
}

\begin{abstract}
The Black Appalachian educational experience during the civil rights era has largely been obscured by mythologies of invisibility and regional racial innocence. The narrative in this article counters these myths through the stories of Black Appalachians who came of age during the 1950s and 1960s in Jenkins, a southeastern Kentucky coal town. It explores the nuances and complexities of Jim Crow in this Appalachian community and demonstrates the various ways in which the Black community navigated segregation and inequality through its commitment to education as freedom. The belief in the liberatory potential of education fostered different forms of activism, from direct-action protest to more subtle acts of resistance. This article uses oral histories to reconstruct the educational experiences of Black Appalachians during a particular transformative moment in history. Prioritizing the voices of those who lived this history not only highlights the agency of Black Appalachians, but also assigns subjectivity and agency in constructing the narrative itself.
\end{abstract}

Keywords: Black education; civil rights; activism; Appalachia; segregation; oral history

In May of 1963, eleven students from the all-Black Dunham High School (DHS) in Jenkins, Kentucky, walked to a local restaurant and quietly sat down to eat at the counter that was traditionally reserved for White patrons. The local newspaper proudly reported that the "students were served without incident." A month later, in anticipation of the passage of the Civil Rights Act of 1964, Kentucky Governor Bert Combs issued an executive order that banned racial discrimination in all establishments professionally licensed by the state. ${ }^{2}$ This order extended into the coalfields of eastern Kentucky, where some school districts and other public spaces remained segregated for years following the 1954 Brown v. Board of Education decision. ${ }^{3}$

\footnotetext{
1"Sit-in at Jenkins Ends Without Incident," (Whitesburg, KY) The Mountain Eagle, May 23, 1963, n.p. The town of Jenkins, Kentucky, is in Letcher County, in the southeastern part of the state bordering southwest Virginia. Sometimes southeastern Kentucky and eastern Kentucky are used interchangeably. For a map of Kentucky counties, see https://www.worldatlas.com/upload/b7/86/f7/kentucky-counties-map.png.

2"Order Bans Bias," The Mountain Eagle, June 27, 1963, n.p.

${ }^{3}$ Eastern Kentucky is part of the Central Appalachian subregion of Appalachia. While there has been a long debate on the demarcations of Appalachia, this research focuses on one community in the Central (C) History of Education Society 2021
} 
Nearly a decade passed after "all deliberate speed" before many coalfield school districts finally desegregated their schools. ${ }^{4}$ By the 1950s and 1960s, these mountain towns and hamlets had already lost a significant number of their Black population, consisting primarily of southern Black migrants who had settled in the eastern Kentucky coalfields during the late nineteenth and early twentieth centuries in hopes of escaping the Deep South's oppressive Jim Crow regime as well as seeking fairer wages and better opportunities for their families. ${ }^{5}$

By the late 1960s and early 1970s, only a small Black population remained. Several scholars and activists surveyed the area and, having observed the regional realities of both racism and poverty, concluded that the civil rights movement never reached the mountains. ${ }^{6}$ Scholar Fayetta Allen has noted that the Reverend Martin Luther King and the Southern Christian Leadership Conference chose not to organize in the region because they believed that a nonviolent strategy would prove ineffective in a predominantly White area. She observes that Black Appalachians seemed "to be unaware of the lack of control they have over their lives" in their corporate-controlled and majority-White towns. ${ }^{7}$ Other scholars have noted that "visible black political action did not take place in rural Appalachia-the coal towns-" in the absence of urban centers and a sizable Black population. ${ }^{8}$ Black Appalachians had also been

Appalachian coalfields. This article uses the term Appalachia to refer to the Central Appalachian region. However, it is important to note that just as Appalachia cannot be considered a monolith, neither can its subregions. The social, cultural, and political contexts of Appalachian coal towns should be examined with nuance. This narrative represents the experiences of those who lived and made their history in the Jenkins community and is not meant to be wholly representative of the region. However, it suggests that similar historical patterns may be worthy of further exploration in other coal mining communities within the region.

${ }^{4}$ The ruling from Brown II mandated "all deliberate speed," which led to many school districts prolonging or evading desegregation. Richard Kluger, Simple Justice: The History of Brown v. Board of Education, the Epochal Supreme Court Decision that Outlawed Segregation, and of Black America's Century-Long Struggle for Equality Under Law (Random House Publishing, 1975), 742-44.

${ }^{5}$ Ronald L. Lewis, "From Peasant to Proletarian: The Migration of Southern Blacks to the Central Appalachian Coalfields," Journal of Southern History 55, no. 1 (Feb. 1989), 77-102.

${ }^{6}$ Clarence Wright, "Black Invisibility-Myth or Reality?," Black Appalachian Viewpoints 1, no. 1 (1973), 1-3; Fayetta A. Allen, "Blacks in Appalachia," Black Scholar 5, no. 9 (June 1974), 42-51; and Edward J. Cabbell, "Black Invisibility and Racism in Appalachia: An Informal Survey," Appalachian Journal 8, no. 1 (Autumn 1980), 48-54.

${ }^{7}$ Allen, "Blacks in Appalachia," 48. Note that the Highlander Folk School was located in eastern Tennessee, where many civil rights leaders and activists (including Dr. King and Rosa Parks) trained and participated in workshops focused on activism.

${ }^{8}$ William H. Turner, introduction to Blacks in Appalachia, ed. William H. Turner and Edward J. Cabbell (Lexington: University Press of Kentucky, 1985), xxi. Note that there are documented attempts and efforts to organize and advocate for civil rights in eastern Kentucky. First, there is evidence of NAACP chapters organized in eastern Kentucky in the 1940s. See George C. Wright, A History of Blacks in Kentucky: Volume 2: In Pursuit of Equality, 1890-1980 (Frankfort: Kentucky Historical Society, 1992). A chapter in Harlan County, Kentucky, held sit-ins at some local establishments with "mixed results." See Alessandro Portelli, They Say in Harlan County: An Oral History (Oxford, UK: Oxford University Press, 2011), 289. Organizational efforts to make connections between labor and civil rights during the broader movement did not focus specifically on Black Appalachians. In the spring of 1964, the Appalachian Committee for Full Employment and the Students for a Democratic Society (SDS) co-sponsored a conference in Hazard, Kentucky, in hopes of organizing unemployed White miners around civil rights issues. However, these endeavors were short-lived and the students went back to school. See Portelli, They Say 
overwhelmingly neglected by federal policy that conveniently focused its attention and efforts on poor White people during a movement in which poor Black Americans across the country, and especially in the South, were fighting for equal rights and a true democracy. ${ }^{9}$

Yet Black Appalachians were also aware of the injustices of separate and unequal during this transformative moment. During a period of "awakening" in which college and high school students participated in nationwide sit-ins to protest racial discrimination in public spaces, a group of Black high school students in Jenkins demonstrated with their own sit-in in their small, quiet, predominantly White town. ${ }^{10}$ Jenkins was a town in which Black and White men worked together underground and where segregation, with the exception of schools, was not enforced through the use of signs that proclaimed "Whites-only" but instead through unwritten customs and social norms. The Black community in Jenkins understood the unwritten rules about sitting down and being served in this local restaurant. But on that late spring day in 1963, a group of students made a decision to walk inside and sit down.

The Jenkins sit-in illustrates that Black Appalachians also sought freedom and full citizenship-they too held a part of "freedom's light." ${ }^{11}$ However, their experiences during the height of the civil rights movement continues to be significantly underexamined or misunderstood. The realities of discrimination and racism as well as resistance and activism in Appalachia have been silenced by the enduring myth of Black "invisibility" in the region. ${ }^{12}$

The mythmaking of White Appalachia not only relegated its Black population to the margins of history, it also produced an enduring sentiment that the region is historically exceptional in terms of race relations compared to the South. ${ }^{13}$ This

in Harlan County, 278-79. Additionally, a 1964 field report from Sam Shirah of the Southern Student Organizing Committee (SSOC) to the Student Nonviolent Coordinating Committee (SNCC) details the organization's intentions to organize White communities in Hazard and Appalachia, Virginia (a town in southwest Virginia) in alliance with the broader Black struggle to fight "poverty, racism, and autocracy." The report explains that misunderstandings prohibited organizing in these places; instead, the SSOC planned to do so in east Tennessee with assistance from the NAACP, Highlander Center, and the Southern Conference Educational Fund (SCEF). See Sam Shirah, "Report to SCEF and SNCC," May 16, 1964, Civil Rights Movement Archives, https://www.crmvet.org/lets/640516_sncc_shirahreport.pdf.

${ }^{9}$ Leon F. Williams, "The Vanishing Appalachian," in Turner and Cabbell, Blacks in Appalachia, 203; and Elizabeth Catte, What You Are Getting Wrong About Appalachia (Cleveland, OH: Belt Publishing, 2018), 59.

${ }^{10}$ For more on the sit-in movement, see Clayborne Carson, In Struggle: SNCC and the Black Awakening of the 1960s (Cambridge, MA: Harvard University Press, 1995). C. Vann Woodward refers to this awakening as a time in which youth were in the vanguard of the movement. See Woodward, The Strange Career of Jim Crow: A Commemorative Edition (Oxford, UK: Oxford University Press, 2002), 170.

${ }^{11}$ Charles M. Payne, I've Got the Light of Freedom: The Organizing Tradition and the Mississippi Freedom Struggle (Berkeley: University of California Press, 2007), 5.

${ }^{12}$ Clarence Wright, "Black Invisibility-Myth or Reality?"; and Edward J. Cabbell, "Black Invisibility and Racism in Appalachia," 48. Both Wright and Cabbell highlight the problems associated with Black "invisibility" in Appalachia.

${ }^{13}$ On the myths of Black invisibility and racial innocence, see Wright, "Black Invisibility-Myth or Reality?," 2-3; and John C. Inscoe, ed., introduction to Appalachians and Race: The Mountain South from Slavery to Segregation (Lexington: University Press of Kentucky, 2001), 2; and Barbara Ellen Smith, "De-gradations of Whiteness: Appalachia and the Complexities of Race," Journal of Appalachian Studies 10, no. 1 (Spring 2004), 38-57. See also Catte, What You Are Getting Wrong About Appalachia, 125; 
myth of racial innocence has historically constructed both a geographical and ideological border that erroneously separates the region from the evils of slavery and Jim Crow. The presence of myths concerning Black invisibility and racial innocence do not designate a distinct and "other" Appalachia, separate from the South and rest of the nation; they have simply enjoyed endurance in White Americans' imagination. ${ }^{14}$ This mythologization of Appalachia perpetuates a master narrative that silences the Black experience and obscures the complexities and realities of race relations in the coalfields during a transformational period in the country's history. ${ }^{15}$

This paper contributes to the existing literature on Black education and civil rights in the South by addressing critical voids within three historiographical strands. First, it seeks to recover a critical historical moment in the Black Appalachian historiography by reexamining the experiences of Black Appalachians during the "classical" civil rights period. ${ }^{16}$ Second, it confronts the historiographical tension around the myth of regional racial innocence by examining the complexities of Jim Crow in a southeastern Kentucky coal mining community during an era of significant sociopolitical shifts experienced throughout the country. Finally, it extends the Black educational historiography to include a region often overlooked as a result of mythology and censure.

This narrative will proceed in three parts: the first part will critically examine the Appalachian mythology of race that has rendered the historiographies of Appalachia, civil rights, and Black education incomplete. This section will also provide the

and Jessica Wilkerson, To Live Here, You Have to Fight: How Women Led Appalachian Movements for Social Justice (Urbana: University of Illinois Press, 2019), 8.

${ }^{14}$ Anthropologist Allen Batteau has called Appalachia a "creature of the urban imagination" and a "literary and political invention" created by novelists, journalists, and many others. He advocates for an understanding of the relationship between the region's "mythical images and historical realities." See Batteau, The Invention of Appalachia (Tucson, AZ: The University of Arizona Press, 1990), 1. See also Henry D. Shapiro, Appalachia On Our Mind: The Southern Mountains and Mountaineers in the American Consciousness, 1870-1920 (Chapel Hill, NC: The University of North Carolina Press, 1986). For more on Southern mythmaking, see Paul M. Gaston, The New South Creed: A Study in Southern Mythmaking (Montgomery, AL: NewSouth Books, 1970). Sometimes Appalachians themselves have perpetuated myths about the region. Harry Caudill, a local lawyer from Whitesburg, Kentucky, demonstrated how outside capitalists historically exploited the land and people of eastern Kentucky, claiming this exploitation left the mountaineers helpless and hopeless. See Harry M. Caudill Night Comes to the Cumberlands: A Biography of a Depressed Area (Boston: Little, Brown, 1962). Elizabeth Catte refers to Caudill as a "translator of white mountain poverty to the nation." See Catte, What You Are Getting Wrong about Appalachia, 80.

${ }^{15}$ I use the term "race relations" in an effort to be consistent with past literature. While I acknowledge that this term appears to be neutral, relations between Black and White community members must be critically examined in terms of power dynamics, which historically have been unequal. I use the term "master narrative" to refer to a top-down, dominant historical narrative that obscures or marginalizes other historical perspectives. Julian Bond argued that the master narrative of the civil rights movement obscured the complexities of the movement. See Payne, I've Got the Light of Freedom, xiii-xiv. For more on master narratives of the civil rights movement, see Jacquelyn Dowd Hall, "The Long Civil Rights Movement and the Political Uses of the Past," The Journal of American History 91, no. 4 (March 2005), 1233-1263; and Derrick P. Alridge, "The Limits of Master Narratives in History Textbooks: An Analysis of Representations of Martin Luther King, Jr." Teachers College Record 108, no. 4 (April 2006), 662-686.

${ }^{16}$ Civil rights activist Bayard Rustin used the term "classical" to refer to the period that spanned the 1954 Brown v. Board decision to the Civil Rights Act of 1964. See Bayard Rustin, "From Protest to Politics: The Future of the Civil Rights Movement," in Looking Forward: No. 1 in a Series of Occasional Papers (New York: League for Industrial Democracy, 1965), https://www.crmvet.org/docs/rustin65.pdf. 
historiographical context of civil rights and Black education in the South to situate the narrative within the historiography. The second part will discuss the social, economic, and political contours of Jim Crow during the first half of the twentieth century in Jenkins, a southeastern Kentucky coal town. The last part will illustrate the various ways in which Black Appalachians interpreted, experienced, and ultimately resisted Jim Crow in the town.

\section{Appalachian Mythmaking and a Critical Examination of Historiography}

Scholars, writers, and policymakers have primarily depicted Appalachia as a racially and culturally homogenous region since it was first written about in the late nineteenth century and then rediscovered as a subject for research in the 1960s. In 1964, when President Lyndon B. Johnson declared a "war on poverty" from a front porch in eastern Kentucky, an image of a folk subculture in which the region's inhabitants were peculiar, backward, and overwhelmingly White became cemented in the nation's consciousness. ${ }^{17}$ White civil rights activists who had worked with Black activists further south began to turn their attention to poverty in Appalachia. ${ }^{18}$ This whitewashing of Appalachia and its poverty further obscured the region's Black population and the struggle for civil rights. ${ }^{19}$

Central Appalachia's geographic features have also been utilized to perpetuate myths about Black invisibility and racial innocence. In his 1916 essay "Freedom and Slavery in Appalachian America," Carter G. Woodson noted that the region's mountainous terrain was physically inconducive to a plantation economy. Additionally, he depicted White mountaineers as a "kind and beneficent" class whose quest for freedom and religious practices precluded the establishment of slavery as a viable institution. ${ }^{20}$ Some scholars used Woodson's early depiction of Appalachia to argue that slavery was not prominent in most of the region, while others have since illuminated the ways scholars of Appalachia have since illuminated the ways in which White Appalachians benefited from and were complicit in slavery. ${ }^{21}$ Recent studies have concluded that the region's "racial practices" were "uneven," while mountaineers' "racial attitudes were often paradoxical."22

In the last few decades, historians have written Black Appalachians and their experiences and contributions into the Appalachian historiography. ${ }^{23}$ These studies have

\footnotetext{
${ }^{17}$ Dwight B. Billings and Kathleen M. Blee, The Road to Poverty: The Making of Wealth and Hardship in Appalachia (Cambridge, UK: Press Syndicate of the University of Cambridge, 2000), 13; and Williams, "The Vanishing Appalachian," 203. Following this declaration, Congress passed the Appalachian Regional Development Act in 1965, which allowed for billions of dollars in federal funding and the establishment of the Appalachian Regional Commission (ARC) that overwhelmingly targeted White Appalachians. In 1969, the Black Appalachian Commission (BAC) was established in order to organize Black Appalachians around issues of racism and poverty. See Allen, "Blacks in Appalachia." The BAC was no longer functioning after 1975. See Cabbell, "Black Invisibility and Racism," 51.

${ }^{18}$ Wilkerson, To Live Here, You Have to Fight, 7.

${ }^{19}$ Catte, What You Are Getting Wrong About Appalachia, 81.

${ }^{20}$ Carter G. Woodson, "Freedom and Slavery in Appalachian America," Journal of Negro History 1, no. 2 (April 1916), 132-50.

${ }^{21}$ Inscoe, Appalachians and Race.

${ }^{22}$ Thomas E. Wagner and Philip J. Obermiller, African American Miners and Migrants: The Eastern Kentucky Social Club (Champaign: University of Illinois Press, 2004), 6.

${ }^{23}$ Turner and Cabbell's Blacks in Appalachia, published in 1985, was the first anthology of essays on the experiences of Black Appalachians-importantly, it acknowledged that Black people have always been in the
} 
paid particular attention to both antebellum Appalachia and the experiences of the southern Black migrants who traveled to the coalfields during the late nineteenth and early twentieth centuries in search of better opportunities than they were afforded in the Jim Crow South. These scholars were particularly interested in the racial attitudes of White mountaineers as well as the status of race relations in the region, as primarily examined through the lens of labor and the workplace. While most studies contend that segregation existed to various degrees within the coalfields, scholars have offered diverse interpretations on race relations. ${ }^{24}$ David Corbin has argued that in southern West Virginia, the coal company's control over the town and practice of "social and racial parity" in areas such as jobs and housing mostly prevented racial hostility. ${ }^{25}$ In turn, Black and White workers were able to develop interracial solidarity through a "common class consciousness" that allowed miners to confront capitalistic oppression. ${ }^{26}$ Other scholars have claimed that coal towns were significantly stratified along racial lines. ${ }^{27}$ Still, historian Joe Trotter and others have argued that Black miners were not passive regarding racist practices and actively resisted them through organizing, creating their own institutions, occasionally forging interracial alliances, and ultimately moving on if their demands were not met. ${ }^{28}$

While scholars have examined race relations and the early twentieth century Black migrant experience, there remains a lack of mid-twentieth-century scholarship on Black Appalachia. This void has prevented an accurate understanding of Appalachian race relations during the 1950s and 1960s, further buttressing the myth of a racially innocent Appalachia. ${ }^{29}$ Following the Second World War, the Appalachian coalfields experienced a mass outmigration of its Black population. The 1930s era of automation disproportionately displaced Black miners, while the late 1940s coal bust forced many workers, Black and White, to leave the region in

Appalachian mountains. Inscoe's Appalachians and Race provided accounts on antebellum Appalachia. For notable works on coalfield race relations and the Black migrant miner experience, see Ronald L. Lewis, Black Coal Miners in America (Lexington: University Press of Kentucky, 1987); Ronald L. Lewis, "From Peasant to Proletarian: The Migration of Southern Blacks to the Central Appalachian Coalfields," Journal of Southern History 55, no. 1 (1989), 77-102; and Joe W. Trotter Jr., Coal, Class, and Color: Blacks in Southern West Virginia, 1915-1932 (Champaign: University of Illinois Press, 1990). On the Black migrant experience and education, see Karida L. Brown, Gone Home: Roots and Race Through Appalachia (Chapel Hill, NC: University of Chapel Hill Press, 2018).

${ }^{24}$ Ronald L. Lewis has pointed out that race relations in West Virginia were often misinterpreted. See Lewis, Black Coal Miners of America, 148.

${ }^{25}$ David A. Corbin, "Class over Caste: Solidarity in the Company Town," in Turner and Cabbell, Blacks in Appalachia, 98.

${ }^{26}$ Corbin, "Class over Caste," 93-113.

${ }^{27}$ Studies that highlight racism and segregation in the coalfields include Trotter Jr., Coal, Class, and Color; and Brown, Gone Home. Note that most historical studies examining race relations in the coal camp have focused on West Virginia, which boasted the largest Black population at the time.

${ }^{28}$ Trotter Jr., Coal, Class, and Color, 53; and Wagner and Obermiller, African American Miners and Migrants, 35-51.

${ }^{29}$ Scholar Barbara Ellen Smith also draws this conclusion. See Smith, "De-gradations of Whiteness: Appalachia and the Complexities of Race," 38-57. Gerald L. Smith also laments the lack of twentiethcentury scholarship, both in general and on civil rights history in places other than Kentucky's urban centers. See Gerald L. Smith, "Straining to Hear Their Thoughts and Desires: Researching and Writing the African American Experience in Kentucky," Register of the Kentucky Historical Society 113, no. 2/3 (Spring/Summer 2015), 509-41. 
search of work in the North and Midwest. While scholars have concluded that a small Black population remained in the coalfields, this postindustrial population, including a generation born and raised in Appalachia, has remained virtually unexamined within the historiography. Due to both the "invisibility" of Black Appalachians beyond the early twentieth century as well as the myth of Whiteness and racial innocence, Appalachia has often been largely ignored within the civil rights historiography.

Because of this dearth in scholarship, little is known about how Black Appalachians experienced and participated in the Black freedom struggle for full citizenship and educational equity. ${ }^{30}$ For Black Americans, education has historically been tied to freedom. ${ }^{31}$ Several important studies have highlighted the selfdetermination and agency of Black southerners who believed in the liberating power of education and who historically organized for it by founding, funding, and constructing their own schools, both before and after Emancipation. ${ }^{32}$ Black families in the South continued to struggle for equitable resources, facilities, and materials when their schools were consistently underfunded by White legislators. For some families, the path to liberation was through full desegregation..$^{33}$ For others, it was in the equalization of resources for their all-Black school, which represented an important cultural center whose administrators and teachers instilled a sense of collective identity and pride in their students. ${ }^{34}$ If Brown was prescribed as the remedy for separate and unequal, then it did not fulfill its promise. Southern school districts continued to evade the ruling until forced to take action, which often meant massive White resistance and the abandonment of public education. It also meant the loss of

\footnotetext{
${ }^{30}$ For an exception to the lack of scholarship on the Black Appalachian educational experience during the civil rights movement, see Brown, Gone Home, 103-158. However, more studies are warranted to avoid treating Appalachia as a monolithic region. Conditions can vary across local contexts due to social, political, and economic factors-even within the same subregion.

${ }^{31}$ James D. Anderson, The Education of Blacks in the South, 1860-1935 (Chapel Hill: University of North Carolina Press, 1988).

${ }^{32}$ Adah Ward Randolph, "Presidential Address: African-American Education History-A Manifestation of Faith," History of Education Quarterly 54, no. 1 (Feb. 2014), 1-18. Several studies have highlighted Black self-determination and agency in the struggle for education. See Anderson, Education of Blacks in the South; Vanessa Siddle Walker, Their Highest Potential (Chapel Hill: University of North Carolina Press, 1996); Heather A. Williams, Self-Taught: African American Education in Slavery and Freedom (Chapel Hill: University of North Carolina Press, 2007); and Ronald E. Butchart, Schooling the Freed People: Teaching, Learning, and the Struggle for Black Freedom, 1861-1876 (Chapel Hill: University of North Carolina Press, 2010). Other studies examining Black cultural capital and agency include V. P. Franklin, introduction to Cultural Capital and Black Education: African American Communities and the Funding of Black Schooling, 1865 to the Present (Greenwich, CT: Information Age Publishing, 2004); Carter J. Savage, "Cultural Capital and African American Agency: The Economic Struggle for Effective Education for African Americans in Franklin, Tennessee, 1890-1967," Journal of African American History 87 (Spring 2002), 206-35; and Christopher M. Span, "I Must Learn Now or Not at All': Social and Cultural Capital in the Educational Initiatives of Formerly Enslaved African Americans in Mississippi, 1862-1869," Journal of African American History 87 (Spring 2002), 196-205.

${ }^{33}$ Francoise N. Hamlin, Crossroads at Clarksdale: The Black Freedom Struggle in the Mississippi Delta After World War II (Urbana: University of Illinois Press, 2012).

${ }^{34}$ For more on the cultural importance of all-Black schools, see David S. Cecelski, Along Freedom Road: Hyde County, North Carolina, and the Fate of Black Schools in the South (Chapel Hill: University of North Carolina Press, 1994); Walker, Their Highest Potential; and Brown, Gone Home.
} 
Black cultural institutions and community after the burden was disproportionately placed on the Black community to "integrate" into previously all-White schools. The commonality that unites these southern cases is grounded in the fact that the Black struggle for educational opportunity has always been juxtaposed against White resistance.

While the distinctive geographical context of Appalachia physically separated the coalfields from both the Deep South and the contentious racial battleground of northern cities, the mountains did not insulate the region from racism and discrimination. This is illuminated in both Jenkins's separate and unequal educational facilities and the ways in which the school district responded to the landmark Brown decision by prolonging desegregation until finally forced to comply. Even then, change did not come swiftly. Some members of the White community continued to resist even after civil rights legislation in hopes of preserving the status quo in their small mining town.

Meanwhile, members of the Black community were challenging the social order that had tried to pacify them with "separate but equal." Higher education had begun opening its doors to Black students as the dangerous and unpredictable coal industry was experiencing decline. ${ }^{35}$ Many parents had always believed in the transformative powers of education and wanted their children to have the option of a life free from hard labor and coal dust. ${ }^{36}$ Because of this faith, Black parents, teachers, and the principal at DHS supported their students in various ways. They advocated and secured resources and opportunities for their segregated school and prepared students for the impending desegregation that would forever alter the Black community. When school desegregation failed to bring about social change in other aspects of community life, Black youth responded with their own small acts of protest and activism to demand full citizenship in the coalfields. ${ }^{37}$ These acts of advocacy, both large and small, empowered Black youth to graduate high school and to choose their own educational and career paths. This ability to dream of possibilities other than coal was in itself radical; for many, the ultimate act of resistance occurred in leaving the coalfields to seek full citizenship and freedom. ${ }^{38}$

\footnotetext{
${ }^{35}$ In addition to new opportunities in higher education, many Black Appalachians in southeast Kentucky had familial connections in both the deeper South and North and Midwest as a result of the Great Migration. Karida Brown argues that these connections and exposures to life outside of the coalfields also ultimately helped prepare youth for migration. See Brown, Gone Home, 163-64.

${ }^{36}$ For more on Black parents' faith in education, see Randolph, "Presidential Address."

${ }^{37}$ For important scholarship on student activism and the civil rights movement, see R. Scott Baker, Paradoxes of Desegregation: African American Struggles for Educational Equity in Charleston, South Carolina, 1926-1972 (Columbia: University of South Carolina Press, 2006); and Jon N. Hale, The Freedom Schools: Student Activists in the Mississippi Civil Rights Movement (New York: Columbia University Press, 2016).

${ }^{38}$ This idea of dreaming of other radical possibilities is similar to what Robin D. G. Kelley refers to as "freedom dreams," in which he calls for spaces in which Black visions and imaginations of humanity and liberation can be cultivated and realized. See Kelley, Freedom Dreams: The Black Radical Imagination (Boston: Beacon Press, 2002), 198. This article about Black education in Appalachia argues that the mundane and ordinary spaces of school and community nurtured the dreams of Black Appalachian youth.
} 
This article examines the experiences of Black Appalachians who came of age in a segregated coal town during the height of the struggle for civil rights, as told primarily through their perspectives and remembered over half a century later. ${ }^{39}$ This story is not simply one of White resistance and how Black citizens responded to segregation and discrimination. Instead, it highlights the desire of Black Appalachians to "live full and free lives." It reveals the ways in which this desire was reflected in "everyday acts of resistance" in their struggle for education and full citizenship and complicates interpretations of activism during the civil rights movement by examining the experiences of a population and region that have been understudied. ${ }^{41}$ What were the social and economic contours of Jim Crow in eastern Kentucky, and how did the Black community interpret its impact on their daily lives? How did conceptions of humanity and democracy enable the Black community to challenge separate and unequal in the Mountain South? In what ways did Black Appalachians demand educational equity and full citizenship in their predominantly White coal town, where they were expected to accept Jim Crow conditions as defined by Appalachia rather than the Deep South? The following narrative offers answers to these questions and, in doing so, directly counters the mythology of both Black invisibility and racial

\footnotetext{
${ }^{39}$ Brown's Gone Home also relies heavily on oral history interviews with those who migrated to and from Harlan County, Kentucky. This article aims to extend the literature on the Black Appalachian experience in eastern Kentucky with a specific focus on various forms of activism against separate and unequal. A note on memory and oral history: Italian scholar Alessandro Portelli completed an extensive oral history study of Harlan County, Kentucky, in the 1980s. He refers to the oral history process as not simply storytelling but "history-telling" that is produced through the interaction between interviewer and narrator. "Therefore, while memory is the stuff of both story-telling and history-telling, the latter is also specifically about memory. The space and time of history-telling sessions, therefore are in themselves a lieu de memoire [site of memory] [emphasis in original]." Alessandro Portelli, "History-Telling and Time: An Example from Kentucky," Oral History Review 20, no. 1/2 (Spring-Fall 1992), 52. This idea of memory space comes from French historian Pierre Nora to explain collective memory-that places, objects, or events can be important to how a group remembers. See Pierre Nora, "Between Memory and History: Le Lieux de Mémoire," special issue, Representations 26 (Spring 1989), 7-24. When possible, I have attempted to triangulate interviews with other sources. However, as a critical scholar, I recognize and privilege narrators' stories as history they lived and made: "The importance of oral history may not be in its adherence to fact, but rather in its departure from it, as imagination, symbolism, and desire merge." See Alessandro Portelli, "What Makes Oral History Different," in Oral History Reader, ed. Robert Perks and Alistair Thomson (London: Routledge, 2006), 37.

${ }^{40} \mathrm{I}$ advocate for the full experience of Black Appalachians to be rendered visible in histories that position them as subjects with desires and agency rather than simply objects who have been acted upon and oppressed. Luther Adams shares this sentiment about histories on the Black experience in Kentucky. This is what is meant by "full and free lives." See Luther Adams, "My Old Kentucky Home: Black History in the Bluegrass State," Register of the Kentucky Historical Society 113, no. 2/3 (Spring/Summer 2015), 385-419. The quote is on page 391. Furthermore, this article aims to satisfy the approach that Ronald E. Butchart called for in critically examining systems of power and oppression as well as culture-the ways in which "Black people lived, thought, and acted, even for themselves" even in the face of these sources of oppression. Butchart, "Outthinking and Outflanking the Owners of the World': A Historiography of the African American Struggle for Education," History of Education Quarterly 28, no. 3 (Fall 1988), 364-65.

${ }^{41}$ Stephanie M. H. Camp has used the term "everyday resistance" to describe the private and intimate spheres of subtler forms of resistance by enslaved women. See Camp, Closer to Freedom: Enslaved Women and Everyday Resistance in the Plantation South (Chapel Hill: University of North Carolina Press, 2004).
} 
innocence in Appalachia, illuminating the ways in which the Black freedom struggle extended beyond the borders of the Deep South and into the Appalachian coalfields. The students' stories highlight the role of education in Black Appalachians' struggle for full citizenship and the ways in which it fostered both direct-action activism and everyday acts of resistance in the pursuit of liberation. ${ }^{42}$

\section{Jenkins, Kentucky: A Town Built on Coal and the Color Line}

Despite its late development, eastern Kentucky eventually became the second largest coal-producing subregion in Appalachia. ${ }^{43}$ The path was laid in the early 1900s, when extensions to the Louisville and Nashville Railroad made it possible for northern coal companies to penetrate the rich coal seams of Letcher County. By 1912, the Consolidation Coal Company (Consol), a Maryland coal giant, had cleared the surrounding forests to build the town of Jenkins specifically for mining coal. Jenkins was designated as a center of eastern Kentucky's coal operations and developed into a "model" mining town that included churches, a post office, a ballpark, a recreation center, a company store, and "modern" schools. ${ }^{44}$ Model towns were designed to "uplift" the miners' quality of life by providing amenities not found in other company towns in exchange for complete social control by the coal company. ${ }^{45}$ Every establishment and facility was originally owned by Consol, including the hospital and funeral home. This reality was not lost on those who lived in Jenkins; coal miners often joked that Consol brought the town's citizens into the world and then later escorted them out of it. ${ }^{46}$

Consol was similar to other coal companies in that it required labor to meet the demand for coal that could be mined in the region's coal beds; the company also needed to maintain complete control over the workforce. To meet these needs, coal companies recruited European immigrants and Black southerners in order to create a "judicious mixture" among White mountaineers that would work to increase production and profit while maintaining the social order in both the mines and the community. ${ }^{47}$ Thousands of Black southerners migrated north to the Appalachian

\footnotetext{
${ }^{42}$ This research will hopefully contribute to a fuller and more robust history of the civil rights movement. See Jeanne Theoharis, A More Beautiful and Terrible History (Boston: Beacon Press, 2018). This research uses oral histories to construct a counter-narrative that confronts Appalachian mythology and highlights perspectives of the Black community that have been previously marginalized.

${ }^{43}$ Ronald D. Eller, Miners, Millhands, and Mountaineers: Industrialization of the Appalachian South, 1880-1930 (Knoxville: University of Tennessee Press, 1982), 85.

${ }^{44}$ Eller, Miners, Millhands, and Mountaineers, 144; and Geoffrey L. Buckley, Extracting Appalachia: Images of the Consolidation Coal Company, 1910-1945 (Athens: Ohio University Press, 2004), 43. Jenkins, along with other model towns, made up fewer than 2 percent of all Central Appalachian coal towns. See Lewis, Black Coal Miners in America, 147.

${ }^{45}$ Lewis, "From Peasant to Proletarian," 89; and Wagner and Obermiller, African American Miners and Migrants, 12.

${ }^{46}$ Elizabeth Wassum Dramcyzk, The History of Jenkins, Kentucky: Compiled in Honor of the Sixtieth Anniversary Homecoming Celebration, 1912-1973 (Jenkins, KY: North Star Marketing, n.d.), C-4. This edition is actually a reprint of the original, which was compiled and published in 1973 by the Jenkins Area Jaycees.

${ }^{47}$ Eller, Miners, Millhands, and Mountaineers, 170-71; Lewis, Black Coal Miners in America, 144-46; Herbert N. Northrop, "The Coal Mines," in Turner and Cabbell, Blacks in Appalachia, 162; and
} 
Kentucky coalfields for the promise of better wages and living conditions than could be found in the Jim Crow South.

By 1916, Jenkins's Black population totaled 1,379. ${ }^{48}$ If Jenkins was the model town, it was comprised of smaller coal camp subdivisions that included Burdine, Dunham, and McRoberts. In the early years, boarding houses for migrant miners were segregated, but eventually miners rented homes from the company. The quality of coal company houses varied by camp but in general were rented on an equal basis to Black and White families. By the early 1950s, many families owned their homes outright, having bought them from Consol before the company withdrew from the region. ${ }^{49}$

The aesthetics of residential segregation looked a little different depending on the coal camp and sometimes evolved over time. The Black section of the coal camp was often referred to as "colored town." 50 The Tom Biggs section of McRoberts was entirely Black. In other cases, Black and White families lived in the same hollows but on separate ends. This was especially true as the Black population continued to decline from the 1930s to the 1950s. By the 1950s, only a handful of families lived in the Dunham section of Jenkins. Carolyn Hollyfield Rodgers, who grew up in Dunham in the 1950s, recalls growing up in the holler:

That's how we lived. We had White neighbors-one lady used to do doilies and stuff and she would do my mother's doilies for her. The insurance man was a White person and he would come sit down and talk to my mother. I could tell he had been there because it always smelled like cigarettes. The Avon lady was a neighbor-Mom knew everything about her. She knew everything about everybody. We interacted-when my sister got married, the lady across the street, Ms. Puckett, gave my sister a pearl necklace to wear on her wedding day. Mom would have a baby and she'd come upstairs to see the baby. But by the same token, the neighbor that was just beyond her spoke to Mom and Dad and interacted with them, but their grandchildren were saying that when they would make an attempt to come past the grandmother's house, she would tap on the window to tell them to come back. They weren't allowed

Kenneth R. Bailey, “A Judicious Mixture: Negroes and Immigrants in the West Virginia Mines, 18801917," in Turner and Cabbell, Blacks in Appalachia, 117. Note that not all Black southerners migrated voluntarily. Some were "bought" from Southern prisons on guarded trains north to the coalfields. See Eller, Miners, Millhands, and Mountaineers, 170; and Lewis, "From Peasant to Proletarian," 83.

${ }^{48}$ Lewis, "From Peasant to Proletarian," 77-80. Note that in the late nineteenth and early twentieth centuries, a large European immigrant population also came to work the coalfields.

${ }^{49}$ Jenkins Centennial Committee, Jenkins Centennial, 1912-2012: A Celebration of Jenkins Kentucky (2012), 13, Jenkins Public Library, Jenkins, Kentucky; and "Jenkins Coal Co. to Sell Company Houses," The Mountain Eagle, March 21, 1946. This information was found online in The Mountain Eagle's archive section, where excerpts or clippings of former newspapers can be found: https://www.themountaineagle. com/articles/clips-from-available-mountain-eagle-pages-since-our-founding-in-1907-2/.

${ }^{50}$ Eller, Miners, Millhands, and Mountaineers, 170-71. Meanwhile, immigrant families were typically confined to their own hollow, often referred to as a "Hunky Hollow" or "Hunky Row." See Heidi Taylor-Caudill and Whitney Hays, "Immigrants in the Coalfields," March 5, 2014, University of Kentucky Special Collections, http://iia.uky.edu/immigrantsinthecoalfields. 
beyond a certain point. But there they were living with Black people in the holler. There was a White part and a Black part. ${ }^{51}$

This proximity allowed Black and White children some degree of interracial exposure. Additionally, even though they attended separate schools, it was not uncommon for Black and White children to grow up playing together. A. Frazier Curry, who moved to Jenkins when his father accepted the job of principal at the all-Black school, remembers: "You didn't look at things through a Black and White kind of lens. We were children and children played together." ${ }^{.52}$ However, once children reached adolescence, there were instances when boys and girls of different races were no longer allowed to play with each other. This was no different than in other parts of the South where Black and White youth were kept apart socially and in school due to White fears of miscegenation. Lawrence Hollyfield, brother to Rodgers, recalls: "After I reached a certain age, they didn't play with us anymore. I didn't realize at the time what the reason was. But I did later on though." ${ }^{53}$

Jenkins and its "suburbs" were tightly knit together, which meant there were several churches, Black and White, all within a few miles apart. Religion was practiced separately although congregations crossed the color line on occasions. Rodgers explains that she grew up in a predominantly Black church but that her parents had often visited the churches of their White friends:

They'd visit White churches that they would occasionally ping back and forth. And there were people that had some sense of being together that way. But as the years passed my parents started socializing more with the other people. But most of the church was African American. Every once in a while, we would just get impromptu visitors sitting in the back of the church because they came for the music. People would come and listen to the music or they would be a part of the church. I never remember not welcoming other groups of people. $^{54}$

While the Black community could frequent most of the local White-owned businesses and shops, it was understood that Black citizens were not allowed in certain public spaces. This included the swimming pool, which was always located in the "White camp," as well as the recreation center. ${ }^{55}$ The Black community created its own spaces in which they could socialize and enjoy recreation. Rodgers recalls:

\footnotetext{
${ }^{51}$ Carolyn H. Rodgers, interview by author, April 9, 2019.

${ }^{52}$ A. Frazier Curry, interview by author, April 16, 2019.

${ }^{53}$ Lawrence Hollyfield, interview by author, June 18, 2020. Unfounded fears of miscegenation was a common excuse for resisting integration in the South. This was similar to the experiences of Black Appalachians in Harlan County, where events such as homecoming were canceled upon the desegregation of schools. See Brown, Gone Home, 151.

${ }^{54}$ Rodgers, interview. Joe W. Trotter discusses a similar finding of interracial fellowship in West Virginia coal towns in the early twentieth century. However, he described it as a "highly tenuous affair" in which White ministers came and spoke at Black churches but not the inverse. See Trotter Jr., Coal, Class, and Color, 220.

${ }^{55}$ Lois F. Thompson, interview by author, April 7, 2020.
} 
Well, Jenkins had things to offer but they were offered only to the White population there. They had a country club and people played golf and they had a swimming pool and a movie theater when I was growing up. But we weren't allowed to do any of that. There was nothing provided for African Americans to do. We could go to the movie theater but my parents were very religious and they didn't believe in doing sports activities or going to sporting events or dances or that kind of thing. But there were other African Americans that were-they'd have dances and they had what they called almost like a juke joint-where someone would have a house where people would go and dance and party and that kind of thing. ${ }^{56}$

The Black population had to adhere to the rules of Jim Crow in other public spaces, such as the movie theater, where they had to sit in the balcony, as well as a couple of the town's restaurants-they could not sit down to eat at the local drugstore. However, no physical signs designated separate rules for Black and White citizens. Instead, these rules were enforced through unwritten customs or norms that instructed Black citizens of "their place." 57 Charles Reed, who grew up in McRoberts, explains:

That's the way it has been in most southern towns and to some extent-you know, the thing that you have to remember is that when you grow up in the hills of eastern Kentucky or anywhere else in the South, there was always an understanding of what your position was in society. It was bred into everyone and so people knew where they were supposed to be. And when someone was not where you thought they were supposed to be, there were issues. ${ }^{58}$

During the 1950s and 1960s, working and earning conditions were similar for Black and White miners. Jenkins was not only a company town but also a union town. The miners' jobs, wages, and benefits were protected by union membership. ${ }^{59}$ Black citizens who did not work for the company did not enjoy these benefits. Additionally, Black youth in Jenkins had few opportunities to earn extra money through an after-school or summer job. Due to the nature of the town's segregated public and recreational facilities, they were excluded from part-time or seasonal work. In order to make additional money, some would leave the region during the summer to stay with relatives who had migrated to midwestern and northern cities. Jacquline Osley Jackson, who grew up in Dunham, recalls spending summers babysitting in Chicago and Michigan:

Most people, the grownups, they worked in the mines. But as young people and teenagers, we didn't work at all. . . We would have loved to have a job working

\footnotetext{
${ }^{56}$ Rodgers, interview.

${ }^{57}$ This is similar to what Black Appalachians experienced in Harlan County. See Portelli, They Say in Harlan County, 170; and Wagner and Obermiller, African American Miners and Migrants, 44.

${ }^{58}$ Charles E. Reed, interview by author, May 27, 2020.

${ }^{59}$ William Farley, "A Stubborn Courage: Mean and Ornery Journalists in Eastern Kentucky" (PhD dissertation, University of Kentucky, 2017).
} 
even if it was at a swimming pool being a lifeguard or something like that, just any little job, clerking. ${ }^{60}$

While Black and White families in Jenkins may have differed little socioeconomically and occasionally socialized together, an established social hierarchy privileged White citizens over their Black neighbors. The coal company supplied most of the town's jobs and wielded significant influence over the community's economic, political, and social context. This was true for both the original company and its successor, Bethlehem Steel (Beth-Elkhorn Coal Corporation), which bought Consol's properties in 1956. Similar to other Appalachian coal towns, maintaining segregation in aspects of community life served the company's production and profit interests. Maximum production and profit meant maintaining racial harmony, which was possible so long as Black citizens accepted an inferior position within the social order. ${ }^{61}$ Jenkins operated a Jim Crow in which many spaces of business were informally integrated, while most recreational spaces were altogether off-limits to the Black population. The White community determined the rules about when it was acceptable to mix; Black people could patronize their stores but were not welcomed into their country club.

While Jim Crow operated informally in most spaces within the coal town, one exception in which it adhered to formal segregation was education. The Jenkins school system educated Black children separately, even though many students either graduated and went to work in the mines alongside White people or moved away from the area altogether due to displacement and lack of opportunity. School remained a space in which Jim Crow operated formally and legally until Brown, even though the school district remained racially segregated until 1964. While Black and White families may have technically shared a similar economic class status, Jenkins had determined that Black children would be educated in schools with facilities and resources that communicated where Black citizens truly stood within the town's social structure. Jenkins's Black population was too small to threaten White political power, which had been the concern and fear of White planters in the Deep South who kept their Black communities subjugated through underfunded schools and disenfranchisement. Still, the school district in Jenkins continued to resist and evade the Brown decision until desegregation was inevitable.

The generation of Black southerners who originally migrated to the Kentucky coalfields had left southern mines or lives as sharecroppers in rural Alabama and Mississippi, where White-controlled Black public schools were often vastly underfunded and academic calendars shortened due to the demands of the harvest season. ${ }^{62}$ While this coalfield education likely presented an improvement to

\footnotetext{
${ }^{60}$ Jacquline O. Jackson, interview by author, May 6, 2019.

${ }^{61}$ Wright, A History of Blacks in Kentucky. For more on coal company paternalism and exploitation in coal camps, see Wagner and Obermiller, African American Miners and Migrants, 57-67.

${ }^{62}$ For more on Black education in the sharecropping South, see John Dollard, Caste and Class in a Southern Town (Madison: The University of Wisconsin Press, 1957); James C. Cobb, The Most Southern Place on Earth: The Mississippi Delta and the Roots of Regional Identity (New York: Oxford University Press, 1992); and Clyde Woods, Development Arrested: The Blues and Plantation Power in the Mississippi Delta (London: Verso, 2017).
} 
educational opportunity, the Black community in Jenkins did not readily accept inferior educational resources and facilities. Parents, as well as the principal and teachers, continuously advocated for better resources and opportunities that would help prepare their students for full citizenship.

\section{Dunham High School and Community Advocacy Against Separate and Unequal}

The 1904 Day Law prohibited interracial education in Kentucky, and in the eastern part of the state, a dual school system of White and "colored schools" operated the "same in Jenkins as it was in any other community in the United States."63 Originally under Consol, Jenkins operated an independent school system comprised of the city and its subdivisions of Dunham, Burdine, and McRoberts. An independent system granted control of the schools to the company rather than allowing the county to run them. ${ }^{64}$ In districts that operated independently, schools appointed a superintendent and were controlled by a board of education that was elected by the town's citizens. ${ }^{65}$ However, these elections could be influenced by company interests. As in other aspects of community life, the coal company had significant influence on local community politics, including those concerning education. ${ }^{66}$

Black elementary schools operated in Jenkins, Dunham, Burdine, and McRoberts but did not educate children past the seventh grade until 1931. ${ }^{67}$ This was five years before the state legislature required that independent school districts provide at least one twelve-grade school for Black children. ${ }^{68}$ Additionally, because Letcher County had a relatively small Black population, by law it had been relieved of providing a school for Black children due to the high costs of maintaining a school for an

\footnotetext{
${ }^{63}$ Jenkins Centennial, 1912-2012, 55. In 1904, Kentucky legislation passed the Day Law, which prohibited interracial schooling. It was named after Carl Day, an eastern Kentucky state representative who viewed interracial education as a "stench in the nostrils of all true Kentuckians." Before this legislation, Berea College had served a large population of Black students since 1855. William H. Turner, "Between Berea (1904) and Birmingham (1908)," in Turner and Cabbell, Blacks In Appalachia, 14.

${ }^{64}$ F. Rolston, "History of Education in Letcher County, Kentucky" (master's thesis, Graduate School of the University of Kentucky, 1939), 40.

${ }^{65}$ Rolston, "History of Education in Letcher County, Kentucky."

${ }^{66}$ See Corbin, "Class over Caste." Price V. Fishback describes how it was common for company officials to even serve on local school boards. See Fishback, Soft Coal, Hard Choices: The Economic Welfare of Bituminous Coal Miners, 1890-1930 (Oxford, UK: Oxford University Press, 1992). See also Wagner and Obermiller, African American Miners and Migrants, 15.

${ }^{67}$ The consensus around the exact date that Dunham High School was established varies. One possible reason for this confusion is that a "Dunham Colored School" was already operating and eventually had to relocate. While two sources date the high school at 1931, one source suggests that the school opened in 1934 (Rolston, "History of Education in Letcher County, Kentucky," 76). The conflicting dates may be attributed to the fact that although Black students were educated beyond seventh grade beginning in 1931, school board meeting minutes indicate that the district was not able to extend the high school term until 1933 when the district was able to purchase a new bus. Black and White pupils previously shared a bus, riding at different times. See Minutes, Nov. 18, 1933, Board of Education of the Jenkins Graded Common School District, Jenkins Middle High Campus, Jenkins Independent Schools, Jenkins, Kentucky.

${ }^{68}$ William T. Gilbert, "The Administration and Organization of Secondary Schools for Negro Pupils in Eastern Kentucky" (master's thesis, Graduate School of Indiana University, 1948). Kentucky public schools were required to offer a twelve-grade education to all students beginning in 1936. See Wright, A History of Blacks in Kentucky, 160.
} 
undersized population. ${ }^{69}$ The county entered into an agreement with the Jenkins Independent School District (JISD) and agreed to "pay Jenkins Schools for the purpose of maintaining a colored school, all money collected from taxes and money paid into the county school treasury by the state as per capital payment for educating colored children." ${ }^{70}$ The Dunham Colored School, located in the Jenkins subdivision of Dunham, became the county's all-Black high school. However, the county repeatedly failed to uphold its end of the bargain; Consol often had to supplement funding while the JISD regularly resorted to taking loans from its White school fund in order to pay the Black school's teacher salaries and operation expenses. ${ }^{71}$

The company and the school district's investment in Black education for Jenkins and the surrounding area cannot be appreciated without understanding the economic and political context of company towns. Studies have shown that it was advantageous, especially within the first few decades of the twentieth century, for coal companies to provide facilities and help fund Black education in order to attract and maintain "stable families." 72 Because coal companies controlled or influenced the local school boards, the board made educational decisions that would satisfy company interests and appease the Black community while maintaining the status quo.

The Dunham School remained in Dunham until 1942, when Consol constructed a new state-of-the-art preparation plant, or "tipple," near the building. The new coal tipple was loud and disruptive enough that the school building had to be discontinued. ${ }^{73}$ The district then moved the students from Dunham to Jenkins into a woodframe building behind the town's Catholic church and across the street from the all-White Jenkins High School (JHS). ${ }^{74}$ Because Jenkins already had a White high school, the new school was called Dunham High School, even though it served grades one through twelve.

\footnotetext{
${ }^{69}$ Pleasant Moore, "The Status of the Negro Public Secondary Schools of Kentucky" (master's thesis, Indiana State Teachers College, 1931); and Rodgers, interview.

70"Elizabeth Allen-Long Cardwell," interview transcript, 2001, Jenkins Centennial 1912-2012, 66. The 1933 Kentucky Educational Commission report stated that county school districts had to provide for the education of Black children; however, in areas where there was a small population, the State Board of Education could assign control of schooling to centrally located districts and "apportion the costs equably." State Department of Education, Report of the Kentucky Educational Commission (Commonwealth of Kentucky, 1933), 138, https://hdl.handle.net/2027/uc1.\$b64330.

${ }^{71}$ Minutes, Nov. 18, 1933, Board of Education of the Jenkins Graded Common School District; Minutes, May 19, 1934, Jenkins Board of Education, Jenkins Middle High Campus, Jenkins Independent Schools, Jenkins, Kentucky. The Jenkins Graded Common School District soon after became referred to as the Jenkins Independent School District.

${ }^{72}$ Historical accounts that examine Black education in West Virginia describe education as being separate but equal, but note that this may be due to a larger Black population with more political influence. See Fishback, Soft Coal, Hard Choices, 184; and Corbin, "Class over Caste," 93-113.

${ }^{73}$ Fishback, Soft Coal, Hard Choices, 184; Corbin, "Class over Caste," 93-133; and Rodgers, interview. A coal tipple is a large structure that cleans, sizes, and sorts the coal into different loading tracks for transport.

${ }^{74}$ In 1938, the school board discussed building a new high school for Black students in Jenkins. According to the minutes, it is possible that the wood-frame building was the Jenkins Colored Grade School, and it was this building that was expanded into Dunham High School. Minutes, June 16, 1938, Jenkins Board of Education.
} 
DHS began as a four-room building before eventually being expanded to eight rooms. ${ }^{75}$ When a home economics room was added, the district instructed that the addition be constructed from concrete to minimize costs and expedite the renovations. ${ }^{76}$ The school did not have indoor plumbing when the newly appointed principal G. V. Curry arrived in 1951. Two years earlier, the superintendent had discussed the importance of adding a "modern washroom" after the previous restroom had been emptying waste into the creek that ran below the school, but it was not until Principal Curry went before the board to request an indoor restroom that action was finally taken. ${ }^{77}$ Parents also worked to improve their school. In 1952, the DHS PTA raised one hundred dollars in order to add steps to the school's entrance. ${ }^{78}$ In 1956, parents requested hot water for the home economics department, typewriters, and a lunchroom. Their request for a cafeteria was unmet; the board decided there was not enough space and the student population was too small. ${ }^{79}$

The DHS academic plan mirrored the six-year plan at JHS. Students took courses such as English, biology, history, math, music, typing, and home economics. However, because of the lack of space and teachers, Dunham High students were unable to take the complete course load that was offered at the White school. While the school board voted yearly on the adoption of textbooks for the upcoming school term, Dunham High received the used and older-edition textbooks from Jenkins. ${ }^{80}$ Rodgers recalls:

We would get secondhand books from the White school. Never even thought about it until someone told me, "Hey look, this book says 'colored.' So it now goes to the colored school after we have used it." ${ }^{\text { } 1}$

In addition to being issued used and outdated textbooks, Dunham High lacked many of the resources that could be found at JHS. For instance, the Kentucky Power Company (KPC) furnished home economics equipment at JHS that was not available to Dunham. In 1960, Dunham High requested that the school board arrange for KPC to install a washer and dryer as well as a refrigerator, to which the superintendent agreed. ${ }^{82}$ However, this act did not occur without requesting recognition of the board's benevolence. In 1961, the school board made arrangements to procure an appreciation letter from Mrs. Curry-who was both a teacher and the principal's wife-after she had expressed her appreciation for the improvements that had been made to the home economics classroom. ${ }^{83}$

That same year, Principal Curry requested changes to certain classrooms to help reduce foot traffic in the auditorium, which also served as a classroom for part of

\footnotetext{
${ }^{75}$ Rodgers, interview; and Gene Williams, interview by author, Jenkins, Kentucky, March 14, 2019.

${ }^{76}$ Curry, interview.

${ }^{77}$ Minutes, Oct. 18, 1948, Jenkins Board of Education; and Curry, interview.

${ }^{78}$ Minutes, Jan. 21, 1952, Jenkins Board of Education.

${ }^{79}$ Minutes, Sept. 21, 1956, Jenkins Board of Education.

${ }^{80}$ Rodgers, interview; Curry, interview; Jackson, interview; and Thompson, interview.

${ }^{81}$ Rodgers, interview.

${ }^{82}$ Minutes, Sept. 2, 1960, Jenkins Board of Education.

${ }^{83}$ Minutes, Jan. 9, 1961, Jenkins Board of Education.
} 
the day. Meanwhile, parents asked the school board to enlarge the auditorium's stage in order to make it "satisfactory" for additional programs and performances. After they volunteered to provide curtains and the equipment for the project, the superintendent agreed. He also "complimented the representatives from the Negro School for their fine spirit and their willingness to provide some of the things necessary for the improvement of their schools." ${ }^{84}$ Principal Curry acknowledged that these improvements were helpful but that "nothing short of a new building" could meet the needs of the all-Black school. ${ }^{85}$

Parents and patrons from Dunham High also came to school board meetings to make requests and advocate on behalf of the school and its students. In November of 1960, parents came before the board and expressed concerns that their children at Dunham High were not afforded the same opportunities as JHS students due to the lack of resources and course offerings. One parent declared, "Every subject taken in the white schools and not offered in the Negro school places the graduate of the Negro school at a disadvantage when in competition with pupils graduating from a school that offers the necessary subjects for graduation." ${ }^{" 86}$ At a separate meeting, patrons from DHS expressed the need for the high school to be brought to current accreditation standards. The superintendent maintained that raising the standards would require hiring a new teacher for the courses that Dunham High did not currently offer. Paying for both the teacher's salary and the additional space meant withdrawing money from local funds, as the state would not provide funding due to the small population of Black students at Dunham High. ${ }^{87}$ These arguments contradicted the county's rationale for abandoning Black education due to the financial burden two decades earlier. Dual educational systems were in fact expensive to maintain, especially for small student populations. ${ }^{88}$ During the $1950 \mathrm{~s}$ and 1960s, the DHS student population remained small due to the displacement and outmigration of Black families from the region. For example, DHS had only fiftyfive students in its high school population in $1953 .{ }^{89}$

In response, one person suggested putting the schools together if it was entirely impossible to have two accredited high schools, to which the superintendent claimed

\footnotetext{
${ }^{84}$ Minutes of Discussion Meeting with the Negro Citizens, Nov. 28, 1960, Jenkins Board of Education. This example of Black parents providing the necessary materials and resources for schooling is similar to other studies of Black self-determination and schooling. See James D. Anderson, Education of Blacks in the South; Walker, Their Highest Potential; Franklin, introduction in Cultural Capital and Black Education; Savage, "Cultural Capital and African American Agency,"; and Span, "I Must Learn Now or Not at All." The minutes suggest that parents from the White schools also sometimes provided materials to their respective schools, but that the parents of the Black schools worried they would not be able to provide a comparable amount due to their small number.

${ }^{85}$ Minutes of Discussion Meeting with the Negro Citizens, Nov. 28, 1960, Jenkins Board of Education.

${ }^{86}$ Minutes of Discussion Meeting, Nov. 28, 1960, Jenkins Board of Education.

${ }^{87}$ Minutes of Adjourned Session of Meeting, Aug. 8, 1960, Jenkins Board of Education. Note that these minutes were written after Brown and that the district was in gross noncompliance.

${ }^{88}$ School board meeting minutes over the years often discuss the district's financial strains and burdens.

${ }^{89}$ Each narrator discussed how small the student body of Dunham High was-their numbers varied. The local paper reported that in 1953, Jenkins had fifty-five Black high school students and eighty-six Black elementary students. "Jenkins Schools Have Fine Opening, Says Supt. Snapp," The Mountain Eagle, Sept. 3, 1953.
} 
that integration would be unjust to teachers, as some would lose their positions and would be afforded inadequate time to search elsewhere. The patrons responded "that it would be better to let the teachers look out for another position than to let the children be deprived of better education." The group from DHS expected "something to be done between now and the opening of schools to meet their requirements." 90

Parents also advocated for better transportation. Because DHS operated as the county's Black high school, students from Jenkins's subdivisions and nearby towns were bused to Jenkins beginning in the seventh grade or the equivalent of when their current school stopped serving their grade level. ${ }^{91}$ A separate bus for Black children served Jenkins and its surrounding towns. Gene Williams, who grew up in the Tom Biggs section of McRoberts, remembers: "The only thing that separated [McRoberts and Fleming-Neon] from Jenkins were the mountains and the coal tipple, the number seven. There was no road over that mountain. You made a ' $U$ ' to go around it."

The surrounding communities and hollows were small enough that the travel time to pick up and drop off the children was extremely brief. For instance, in the Tom Biggs section of McRoberts, "[The bus] would stop at the head of the holler and then the middle and then the back of the holler and then they'd have all the Black kids."93

The bus driver was usually both a male teacher and the basketball coach. ${ }^{94}$ In the event there were no Black teachers, they would "just hire a Black person that could drive the school bus." 95 The vehicle itself was an older model and in poor condition compared to the buses used for White students at JHS:

I remember standing in the cold, waiting on a school bus that had broken down and it was late. And there sits a school looming right in front of us. The children are already in school, getting their work and I am a young kid with a little six-year-old sister standing on the corner waiting for the school bus that did not arrive until very late because it was broke down. ${ }^{96}$

Between 1959 and 1960, Black citizens from Tom Biggs went before the school board to request better transportation for their children. They complained of overcrowded conditions, to which the superintendent replied that the bus was not more crowded than the buses for White children, and if more children are to be transported to Jenkins, then another bus and driver would have to be employed at an additional expense." He further explained: “The district does not receive for its transportation program a sufficient amount to purchase new buses and pay the amount of up-keep and expenses for gas and oil."

\footnotetext{
${ }^{90}$ Minutes of Adjourned Session of Meeting, Aug. 8, 1960, Jenkins Board of Education.

${ }^{91}$ Rolston, "History of Education in Letcher County, Kentucky," 76.

${ }^{92}$ Curry, interview.

${ }^{93}$ Williams, interview.

${ }^{94}$ Williams, interview.

${ }^{95}$ Williams, interview.

${ }^{96}$ Rodgers, interview.

${ }^{97}$ Minutes, Aug. 8, 1960, Jenkins Board of Education.
} 
On November 7, 1960, parents and citizens formed a line to block the bus for Black students from leaving McRoberts. They were tired of having to send their children on an old bus that was consistently overcrowded and that too often broke down along its short journey. This was especially dangerous during the winter months when it snowed. So they gathered together on what was surely a cool morning in the mountains of Kentucky to prevent the bus from leaving "with a single child on board." ${ }^{98}$ Eventually, the state police forced them to disperse. Upon its release, the bus "wrecked" along a mountainous road, to which the school board assigned a previously used bus to the Black students. ${ }^{99}$ Lois Fields Thompson, who rode the bus from McRoberts to Jenkins, remembers waking in the middle of the night to discover the vehicle in flames:

The superintendent came over to see and they [the parents] told him, "Our kids are not getting on this bus. This bus is dangerous. And we're tired of our kids leaving here and we don't know when they're coming home or if they're coming home. And nine times out of ten they end up sick. So we're not sending our kids." So they didn't. So finally they sent us a halfway decent bus. It broke down too-it wasn't no good either. So something happened. And it was during the night, we heard somebody saying, "There's a fire, there's a fire!" And we looked out the window. The bus was on fire. The bus was on fire. And it was burnt to the ground. So we didn't have school that day. But they did send us a whole lot better bus than what we had had. It was decent enough to get us to school and back. So that's how we got our better bus. ${ }^{100}$

The steps taken to secure adequate transportation demonstrate that members of the Black community were willing to take matters into their own hands after their demands for a better bus had been repeatedly refused. These various accounts of advocacy illustrate that the Black community believed deeply in the transformative potential of education and struggled for equitable educational opportunity for their children. For some, this meant requesting improvements to facilities and procuring better resources for their segregated school. Others sought complete integration if it meant that their children would be afforded the same resources and opportunities as the White students at Jenkins High. ${ }^{101}$ They would not be satisfied with materials, facilities, and resources that prepared their children for second-class citizenship.

In the 1950s and 1960s, parents in the Black community were well aware of the dangers and uncertainty of working in coal. By this time, higher education in

\footnotetext{
${ }^{98}$ Minutes, Nov. 14, 1960, Jenkins Board of Education.

${ }^{99}$ Minutes, Nov. 14, 1960, Jenkins Board of Education.

${ }^{100}$ Thompson, interview. The school board minutes mention the bus accident, but I could not find mention of the bus fire that occurred near that time period. However, there is mention of a bus fire (it is unclear if it was the Black or White bus) in minutes from February 9, 1953.

${ }^{101}$ Because of limited archival documentation and primary sources, it is currently unclear if parents coordinated these different acts of advocacy. School board meeting minutes mention that a group of Black parents planned to organize a committee to discuss desegregation. See Minutes, July 11, 1955, Jenkins Board of Education. Additionally, the bus boycott occurred during the same month that Black parents came to the school board meeting to request better facilities and resources for students.
} 
Kentucky was experiencing desegregation to some extent. The University of Kentucky began admitting Black graduate students in 1949. ${ }^{102}$ After Brown, the university "quietly began admitting" Black undergraduates to all courses. ${ }^{103}$ For the first time, both parents and students were allowed to consider an alternative possibility for themselves rather than coal mining or domestic work. Jackson explains her decision to leave Jenkins:

And I could not stay home-I mean I was there for an X number of years and you know, living there, there just wasn't much. I could see it dying down a little bit. Because everybody that graduated-they left. Even a lot of the Whites. They left. You wanted a better job. My father always told us he didn't want any of my brothers to do the type of work he did because of the many dangers. So he said he wanted us to become educated and leave. ${ }^{104}$

As the barriers to higher education began crumbling, it became more common for parents to gather together and proudly discuss where their children were attending college. ${ }^{105}$ The expectations to further one's education were consistently reinforced by DHS teachers and administration, who "laid the foundation" for student success. Clara M. Reed recalls, "In the sixth grade [at Dunham], my teachers were all African American teachers. And Mrs. Owens and Mr. Webb and Mrs. Clark-they had extremely high standards." 106

Teachers at Dunham not only had high expectations but also promoted a caring environment in which they took a genuine interest in their students, not only as learners but as human beings. As Jackson explains, "They were excellent teachers, they were dedicated teachers, they were caring . . . and they displayed a concern for us as students. They were committed to their work, for one thing. I mean, whatever they taught they wanted us to learn it. ${ }^{107}$ Thompson recalls:

[Mrs. Clark] was really, really a sweet lady. When she got paid she would give me her check and I would take it downtown to the bank and cash it. And she would

\footnotetext{
${ }^{102}$ In 1949, Lyman T. Johnson, a Black teacher from Louisville, was admitted to the University of Kentucky after filing a lawsuit. See Gerald L. Smith, "Straining to Hear Their Thoughts and Desires," Register of the Kentucky Historical Society 113, no. 2/3, 509-41.

${ }^{103}$ A. Lee Coleman, "Desegregation of Public Schools in Kentucky-One Year Afterward," Journal of Negro Education 24, no. 3 (Summer 1955), 249.

${ }^{104}$ Jackson, interview. William H. Turner echoes these accounts, recalling the resilience of Black Appalachians who had to leave the mountains in order to "make something of yourself." William H. Turner, "Black Hillbillies Have No Time for Elegies," in Appalachian Reckoning: A Region Responds to Hillbilly Elegy, ed. Anthony Harkins and Meredith McCarroll (Morgantown: West Virginia University Press, 2019), 232.

${ }^{105}$ A. Frazier Curry, phone conversation with author, September 25, 2020.

${ }^{106}$ Dr. Clara M. Reed, interview by author, May 27, 2020. Derrick Alridge has defined teacher activism as "expressed support for the civil rights movement and the deliberate championing of freedom and equality in teaching/and or community work." Alridge, "Teachers in the Movement: Pedagogy, Activism, and Freedom," HES Presidential Address, History of Education Quarterly 60, no. 1 (Feb. 2020), 4. This article argues that, based on narrators' accounts, Black teachers in Jenkins espoused the ideas of equality and freedom in their high expectations and teachings and, as a result, were engaging in a form of activism.

${ }^{107}$ Jackson, interview.
} 
always tell me to stop by Wilfong [Store] and get her something and she made sure I would get me something. She'd say, "Now don't you come back here without getting you something." And she'd tell me how much I could spend. And it was an honor because she trusted me with her check. ${ }^{108}$

Principal Curry, who had earned his master's degree from Fisk University, believed that "education was the ticket" and that all students deserved one that allowed them to work toward their dreams. ${ }^{109}$ During his time at Dunham High, Mr. Curry fostered a community in which students were both cared for and expected to work diligently in preparing to transition to college if they so desired-and many did seek higher education. Most of the students in the small 1960 graduating class went on to earn their bachelor's degree. ${ }^{110}$

Even as the rest of the state was transforming in the wake of the demand for civil rights, the Jenkins school district resisted change. The school board prolonged desegregation by furnishing the requested materials and resources, even while these were likely to be secondhand. The board often placed the burden upon the Black community to provide its own labor and resources in order to alleviate the board of such obligations, allowing an "opportunity for the citizens to participate in improving their schools."111

As the district rationalized the need to delay desegregation due to limited space, expense, and teacher displacement, it remained defiant to both the Brown ruling and the state of Kentucky's decision to fully cooperate with the decision. ${ }^{112}$ School districts in larger cities with sizable Black populations, such as Lexington and Louisville, began desegregating in the late 1950s. ${ }^{113}$ Meanwhile, Paducah, in the western end of the state, desegregated its schools in $1956 .{ }^{114}$ Rural Wayne County actually offered the state's first desegregation plan in 1956 when the Wayne County Country School opened and admitted five Black students, all from the district's only Black family. ${ }^{115}$ In eastern Kentucky, the Jenkins school board discussed desegregation,

\footnotetext{
${ }^{108}$ Thompson, interview.

${ }^{109}$ Curry, phone conversation.

${ }^{110}$ Curry, phone conversation.

${ }^{111}$ Minutes of Discussion Meeting, Nov. 28, 1960, Jenkins Board of Education.

${ }^{112}$ Following Brown, Governor Lawrence Wetherby declared that his state would "obey the law," immediately appointing a biracial advisory committee that would assist local school districts in the desegregation process. Coleman, "Desegregation of Public Schools in Kentucky," 248-57. The quote is on p. 248. Desegregation would not begin until the 1955-56 school year, and local districts determined the pace of desegregation thereafter. See Coleman, "Desegregation of Public Education in Kentucky," 251. See also John E. Kleber, "As Luck Would Have It: An Overview of Lawrence W. Wetherby as Governor, 19501955," Register of the Kentucky Historical Society 84, no. 4 (Autumn 1986), 397-421.

${ }^{113}$ The urban center of Louisville, Kentucky received national praise for its desegregation efforts. The results were not that simple, though. Tracy E. K'Meyer's study on Louisville addresses how Black children were initially permitted to attend previously all-White schools without serious incident shortly after the Brown decision. However, soon afterward, Louisville and Jefferson County experienced White flight to the suburbs, leading to the resegregation of public education. See K'Meyer, From Brown to Meredith: The Long Struggle for School Desegregation in Louisville, Kentucky, 1954-2007 (Chapel Hill: University of North Carolina Press, 2013).

114"Integration Set for '56 in Paducah," The Mountain Eagle, Sept. 1, 1955.

${ }^{115}$ A. Lee Coleman, "Desegregation of the Public Schools in Kentucky-The Second Year After the Supreme Court's Decision,” Journal of Negro Education 25, no. 3 (Summer 1956), 255.
} 
or what was referred to as a "question of tremendous disturbance," several times following the Brown decision. ${ }^{116}$ However, Jenkins's high schools were not officially desegregated until the 1964-1965 school year. ${ }^{117}$

In preparing for the impending desegregation, DHS teachers, who had long worked to train students for full citizenship, readied them for both the opportunities and challenges that would come with change. This meant discussing the possibility and likelihood that it would not come swiftly even as the schools consolidated. Black students might still be at a disadvantage and would have to compensate for these disadvantages themselves by "working twice as hard."118 The teachers did this because of their steadfast belief in their students' potential, despite being aware that they would likely have to leave Jenkins in order to continue their careers. Although virtually all of the Black teachers held the necessary-if not advanced-certifications, most of them were not hired at JHS following desegregation, which was the case for too many Black teachers across the South. ${ }^{119}$ Those teachers who did make the transition remained only briefly: "They didn't really want you teaching their kids. There was a couple of teachers that transferred over there but they didn't stay very long. The principal immediately left." 120

In 1964, the small number of DHS students entered Jenkins High without facing physical violence. ${ }^{121}$ Black students now had access to courses and resources that the district had previously denied them, but they also lost their school and all-Black teachers, which had both provided community and affirmed their humanity. School desegregation in Jenkins, as in the rest of the South, did not represent the panacea to racial inequality. While Black male athletes could immediately join athletics, the senior prom and trip were cancelled that first year due to White parents' fears of interracial mixing. ${ }^{122}$ White students went on to organize their own gathering at a local establishment. After a couple years, the school-sanctioned events were

\footnotetext{
${ }^{116}$ Minutes, July 11, 1955. Records show that the district received a letter from the state board of education each year inquiring about a desegregation plan.

${ }^{117}$ Minutes, July 11, 1955, Jenkins Board of Education. Note that the high schools desegregated grades 9-12 in 1964 but the JISD followed a gradual plan in which lower grades were not desegregated until the year after. This finding is supported by a few interviews in which students who were younger at the time did not experience full desegregation until the 1965-66 school year.

${ }^{118}$ Rodgers, interview.

${ }^{119}$ In fact, Black teachers often held permanent teaching certificates and master's degrees, whereas many White teachers were consistently employed under emergency certification. See A. Lee Coleman, "Desegregation of the Public Schools in Kentucky-The Second Year," 260. The issuing of emergency certificates was referenced repeatedly in the JISD school board meeting minutes.

${ }^{120}$ Rodgers, interview.

${ }^{121}$ This was dissimilar to many cases of violence in the deep southern states as well as in Sturgis, Kentucky, where the state police and National Guard were called in to protect Black students from a White mob trying to prevent them from entering the newly desegregated high school in 1956 . There was also resistance in Clay and Henderson. See Smith, "Straining to Hear Their Thoughts and Desires," 540.

${ }^{122}$ This was alluded to in an interview with D. Charles Dixon, who was a White teacher and basketball coach at Jenkins High. D. Charles Dixon, interview by author, April 30, 2020. These experiences are similar to what Black students faced when schools were desegregated in Harlan County. See Brown, Gone Home, 151.
} 
eventually reinstated. ${ }^{123}$ These events illustrate that the White community wanted to control the pace of full desegregation and resisted in ways that continued to designate Black students' place within the town's social hierarchy. Black students responded with their own demands for full citizenship.

\section{Change Comes to the Coalfields: Youth Activism Following the Civil Rights Act of 1964}

The passage of the 1964 Civil Rights Act propelled Jenkins to desegregate its public schools and the few businesses, such as the movie theater and local café, that had formerly operated under de facto segregation. However, one establishment continued to resist the new legislation and hold steadfast to its custom of relegating Black citizens to second-class status. Now that Black students had achieved more equitable educational opportunities, they would continue to demand recognition as human beings and citizens. This meant confronting lingering racial discrimination in public spaces.

The local drugstore, which was located next to Jenkins High and across the street from Dunham High, had maintained a reputation for being unwelcoming to the Black community. Well into the 1960s, the owner continued to refuse equal service to Black citizens, who were allowed to enter the restaurant and order at the counter but could not sit in any of the booths. Gene Williams, who graduated from JHS in 1970, compares his past experience with discrimination to present-day experiences of being able to sit down to eat at the drugstore:

It was the only place I felt unwelcome. They told you [that you] weren't welcome and they showed you that you weren't welcome. Showing you is telling you that you can't sit here. And then showing you by escorting you out. If you wanted something, you stand up, you ordered it, you paid for it and then you'd go. Every other place here in Jenkins welcomed Blacks. Now you can go in there and sit [today]. I sit and look around and I can remember that lady telling us you can't be sitting down in here. And I'd say why and she said you just can't. We just ain't started that yet. ${ }^{124}$

One afternoon, Charles Reed, who played basketball for the now "integrated" Jenkins High, came into the drugstore before a game and sat down to eat. When he refused to stand up, the server told him that he would have to leave the restaurant. Again he refused, stating that he needed to eat before his game. When the server returned with the owner, the owner repeated that Reed could not sit and eat. Instead, Reed could walk to the back, tell the cook what he wanted, and leave through the back door. Reed finally got up from his seat. He then walked across the street and bought a placard from the local store and began to march back and forth in front of the restaurant in protest. ${ }^{125}$ The owner called the police, who took Reed to the local jail. When the police officer asked him who he played for, Reed replied that he played

\footnotetext{
${ }^{123}$ Each narrator remembered and spoke of these events.

${ }^{124}$ Williams, interview.

${ }^{125}$ Reed, interview; and Thompson, interview.
} 
for Jenkins and mentioned his coach's name, who was White. This explanation satisfied the officer and Reed was released to his coach so that he could play in his game. $^{126}$

While Reed may have been aware of the national sit-in movement, he was more concerned about asserting his rights as a citizen in the town of Jenkins:

I think it was more a sense that I have a right to be here. And if I'm going to be a productive citizen, I need to assert my right. And sometimes when you're seventeen, eighteen years of age, you don't really understand the amount of danger you're really in. And the thing is . . Jenkins, as you well know, is a small town. So everyone-most people knew the high school athletes. So from that standpoint I wasn't afraid that I would be injured. But I did want to make sure that for those who came behind me that they did have an opportunity to at least sow some of the fruits of being a citizen in that community. ${ }^{127}$

In the late 1960s, high school student Willie Hollyfield wrote to a local civil rights organization to complain about the drugstore's discriminatory treatment of Black patrons. $^{128}$ An official was sent to investigate the situation, which "made [the owner] wake up a little because they could shut you down if you refused service to someone." 129 Hollyfield's parents were shocked because they were originally from Greensboro, Alabama, a town where "you had to step off the sidewalk" if you came across a White person. ${ }^{130}$

Following these events of the one-person picket and letter, the drugstore finally officially desegregated. These examples of protest, along with the 1963 sit-in, demonstrate that Black students not only witnessed social change but actively participated and advocated for this change. Later on, Hollyfield attended Kentucky State University. While there, he published an essay about the continued Black student struggle for liberation in eastern Kentucky as well as across the state:

If you do not liberate these students, they will liberate themselves. The learning process and the thinking process go beyond school walls. You cannot limit the minds of your students in any aspect. They are intelligent enough to seek truth for themselves. $^{131}$

\footnotetext{
${ }^{126}$ Reed, interview; and Thompson, interview.

${ }^{127}$ Reed, interview. This sentiment reflects Ella Baker's assertion that the struggle for civil and human rights was not simply about a hamburger and Coke: "We want the world to know that we no longer accept the inferior position of second-class citizenship. We are willing to go to jail, be ridiculed, spat on, and even suffer physical violence to obtain first-class citizenship." Ella Baker, "Bigger Than a Hamburger," Southern Patriot, May 1960, Civil Rights Movement Archives, https://www.crmvet.org/docs/sncc2.htm.

${ }^{128}$ Rodgers, interview; and Hollyfield, interview.

${ }^{129}$ Rodgers, interview; and Hollyfield, interview.

${ }^{130}$ Rodgers, interview.

${ }^{131}$ Willie Hollyfield, "Viewpoint: The Black Student's Search for a Seat Farther Up Front," (Louisville) Courier-Journal, April 28, 1972, 13. Unfortunately, I was unable to interview Willie, as he has passed away. His siblings, Carolyn H. Rodgers and Lawrence Hollyfield, were kind enough to share his story with me.
} 
These students in Jenkins and the eastern Kentucky coalfields demanded a true democracy in which their lives and humanity would be affirmed in their daily community life. They had come of age in the mountains, been nurtured and inspired by their Black teachers, and encouraged by their parents to achieve their full potential through education. They had witnessed the dismantling of barriers and would not remain satisfied with being treated as second-class citizens outside the classroom.

\section{A Note About Remembering Racism and Civil Rights in the Coalfields}

By the time the JISD began desegregating in 1964, most of the children had grown up with some form of daily contact with White people. It should be reiterated that the narrators in this story came of age during the height of civil rights. Even while growing up in the years of segregation, some were not completely aware of the extent of structural violence in how Jim Crow operated in their coal town. For many, it took years of reflection to better understand the movement and how racism operated in their daily existence in a paternalistic coal community. Only much later did some students better understand why schools were kept segregated for so long. Rodgers, who entered JHS in ninth grade in 1964, explains:

...I think they [the school district] didn't do it until they were forced into it and it gave me a whole different feel about the town I was raised in. . I have to say there probably was some wonderful people there. But they had decided against those people who were not willing to accept that [segregation] as being okaythey wanted to hold on. And they were holding on. They held on until the very end. ${ }^{132}$

Others credited the quality of education that they received in their segregated school, the care of their teachers, and the community created through the small Black population in shielding them from the harsh realities of Jim Crow: "We were aware of segregation and separate schools but as a teenager it didn't really bother us that much because our school was such a community." ${ }^{133}$

Some narrators were not completely convinced that the civil rights movement came to the mountains, even if they were aware of separate and unequal in their town. Almost every narrator could recall the drugstore incident, even though it was not discussed at JHS afterward. The White community pretended that it did not happen. ${ }^{134}$ The fact that the Black population was small and the forms of activism fewer and quieter may have obscured a fuller understanding of the movement, even by some members of the Black community, due to how the civil rights movement has been previously conceptualized and defined. As Williams recalls, "It just seemed like the civil rights era passed us by. We didn't hear nothing about it. It was riots all over in the cities and we would watch them on TV. But nothing ever came here. It was just like this place was forgotten about." ${ }^{35}$ Similarly, Thompson

\footnotetext{
${ }^{132}$ Rodgers, interview.

${ }^{133}$ Curry, interview.

${ }^{134}$ Reed, interview.

${ }^{135}$ Williams, interview.
} 
remembers, “[W]e didn't hear too much about that. We saw some of it but we didn't hear about it until the civil rights movement started. . But even in Jenkins we couldn't sit down and eat."136

These reflections demonstrate the complexities of the ways in which the community interpreted Jim Crow and how it affected the lives of Black families who lived in Jenkins. How Jim Crow was internalized and challenged varied, depending on the backgrounds and experiences of the individuals involved. ${ }^{137}$ Other narrators, such as Rodgers, realized that they were living in an important historical moment for racial justice and social change as they transitioned from adolescence to adulthood:

We'd see it on TV and I understood that changes were happening. I understood it better when I got to college but by then the movement had turned into something else. Martin Luther King had gotten killed in the spring of 1968 and I went to college in the fall of 1968. So the movement had switched over to more of [a] Black Power movement. It was a little different. There were people my age who had taken part in it, who had marched and done certain things as teenagers, but we lived, I felt, more of a sheltered existence. I wouldn't have been allowed to go out there and walk the street and be eat up by dogs or something. I know that [my parents] were glad that change had happened and occurred. But integration came hard for a lot of people because they liked living in their community. They enjoyed that comradery with each other and that kind of thing. And still, I think there are people that would say they enjoyed being segregated. But they knew that it was limiting. There was nothing wrong with living in the communities we lived in-we loved it. But you knew that it was limiting. ${ }^{138}$

\section{Conclusion}

Appalachia has often been depicted as a region geographically and culturally isolated from the rest of America-its inhabitants poor, backward, and White, its Black population invisible, and its history less haunted by the vestiges of slavery and Jim Crow. Because of this, a fuller story of civil rights within the coalfields has yet to be told. Examining the experiences of Black Appalachian youth as they navigated childhood and adolescence in a segregated coal town counters this Appalachian myth, revealing that both racial discrimination and forms of activism existed in the coalfields during the height of the movement for civil and human rights. By extending the borders of the movement into the Kentucky coalfields, we gain a fuller understanding of how it materialized across various geographical, economic, and social contexts.

Many Black Appalachians continued to leave Kentucky in the 1960s and 1970s due to the lack of opportunities available to them. On one hand, there were few

\footnotetext{
${ }^{136}$ Thompson, interview.

${ }^{137}$ Some narrators could not recall times when parents went before the school board to request materials and improvements. One narrator mentioned that his parents' generation "knew their place," which reflects the ways in which Jim Crow permeated daily life. It should also be restated that the parental generation had often migrated from the Deep South. There was nuance to their parents' experiences in Appalachia versus Alabama or Mississippi. I reiterate this and provide this example to demonstrate that this was not a monolithic experience. Historian Gerald Smith affirms that the Black experience in Kentucky was complex but varied by time, place, and circumstance. See Smith, "Straining to Hear Their Thoughts and Desires," 510.

${ }^{138}$ Rodgers, interview.
} 
jobs outside coal in which they could be hired and make a decent living-and even fewer opportunities for women. Meanwhile, working in coal was unpredictable, difficult, and dangerous work. For many Black Appalachian youth, education paved the path toward freedom. Their parents and teachers understood this. Their parents' generation, many of whom had fled a more aggressive Jim Crow in the Deep South, challenged separate and unequal by advocating for better resources for their segregated school and refusing to accept inferior, second-class conditions, as demonstrated by the bus boycott. Meanwhile, the Black principal and teachers consistently reinforced the transformative potential of education through care and high expectations.

This civil rights narrative broadens the definition of activism to include smaller, everyday acts of resistance against separate and unequal. Even if freedom meant choosing to stay and work in the mines, parents and teachers in Jenkins educated Black youth for first-class citizenship and instilled in them a sense that they could imagine other, more radical possibilities. ${ }^{139}$ This preparation helped Black students develop agency and advocate for themselves as citizens, as demonstrated through direct-action protests such as the sit-in and one-person picket. They further resisted second-class citizenship by pursuing higher education, even if this meant they would have to leave the coalfields. These acts of advocacy that prepared Black youth for further education and for life beyond the coalfields were in fact acts of resistance to Jim Crow. Rather than simply being displaced, they acted in ways that enabled them to make their places elsewhere.

Over the past few decades, the production of southeastern Kentucky's coalfields has gradually decreased, causing an outmigration of both Black and White people from the region. This decline has recently accelerated as mine closings and company bankruptcies predict the imminent death of King Coal. Today, Jenkins's population is overwhelmingly White, with a Black population of just over 1 percent. ${ }^{140}$ The local histories either only briefly mention DHS or omit its existence altogether. The building succumbed to fire in 1969, and only the concrete addition remains to suggest the school ever existed. ${ }^{141}$ However, DHS student alumni have recently worked with local officials to preserve the history of their school through a historical marker, which the Kentucky Historical Society granted in 2019. ${ }^{142}$ In May 2021, the town of Jenkins placed an interpretive panel on the main street with historical information written by Carolyn H. Rodgers.

The complete historical record of civil rights and the Black experience in Jenkins can never fully be recovered. However, it is through the testimonies of the Black students who lived this history, who spoke their own dreams into existence, and who demanded recognition of their humanity, that we can begin to recover the Black Appalachian experience during the apex of the movement. Through this recovery, we understand that it would be too simplistic to conclude that the civil rights movement never came to the mountains, for these stories demonstrate that Black

\footnotetext{
${ }^{139}$ Here I refer to bell hooks's concept of "education as the practice of freedom." bell hooks, Teaching to Transgress: Education as the Practice of Freedom (New York: Routledge, 1994), 207.

140“Jenkins, KY," DataUSA, https://datausa.io/profile/geo/jenkins-ky/.

${ }^{141}$ Jenkins Centennial, 1912-2012, 7.

${ }^{142}$ As of August 2021, the marker was placed on the main street of Jenkins.
} 
Appalachians advocated for their civil and human rights through both direct-action protests and everyday acts of resistance. Their stories instead call us to critically reexamine the history of the broader Black freedom struggle, to reconceptualize civil rights activism, and to ultimately recognize the potential of a history of the movement that has yet to be fully realized.

Kristan McCullum is a PhD student at the University of Virginia. She is grateful to the narrators for sharing their stories that helped to construct this narrative. She also thanks both previous and current $H E Q$ editors and reviewers for their thoughtful feedback in the development of this manuscript. This research was supported in part by a Kentucky Oral History Commission oral history project grant.

Cite this article: Kristan L. McCullum, “'They will liberate themselves': Education, Citizenship, and Civil Rights in the Appalachian Coalfields," History of Education Quarterly 61, no. 4 (November 2021), 449-477. https://doi.org/10.1017/heq.2021.46. 